\title{
Exploring affective barriers in virtual exchange: the telecollaborative foreign language anxiety scale
}

\author{
Marta Fondo ${ }^{1}$ and Pedro Jacobetty ${ }^{2}$
}

Abstract

he technological revolution of Information and Communication Technology (ICT) has brought about new learning scenarios as well as new professional requirements,

L such as the development of intercultural and Foreign Language (FL) skills. In this regard, Virtual Exchange (VE) projects provide students with learning opportunities through online social interaction and collaboration (Dooly, 2017); allowing authentic intercultural experiences for students who do not have the opportunity of travelling (O’Dowd, 2016) and promoting 21st-century skills development (Jager, Kurek, \& O’Rourke, 2016). However, interacting online in the FL with a person from a different culture can entail an affective challenge for students and might give rise to Foreign Language Anxiety (FLA). FLA is a dysphoric and situational anxiety suffered by one out of three FL students which inhibits communication and learning (Horwitz, Horwitz, \& Cope, 1986). Due to the impossibility of finding an available tool to investigate the presence and effects of FLA in VE environments, the Telecollaborative FLA Scale (T-FLAS) was designed. This article presents the development of the T-FLAS, a 21-item questionnaire with a five-point Likert scale, aiming to provide researchers and practitioners with a tool to explore FLA in VE.

Keywords: virtual exchange, synchronous computer-mediated communication, foreign language anxiety, anxiety measurement tool, questionnaire.

1. Universitat Oberta de Catalunya; mfondo@uoc.edu

2. The University of Edinburgh; pjacobet@ed.ac.uk

How to cite this article: Fondo, M., \& Jacobetty, P. (2020). Exploring affective barriers in virtual exchange: the telecollaborative foreign language anxiety scale. Journal of Virtual Exchange, 3(SI), 37-61. https://doi.org/10.21827/jve.3.36083 


\section{Introduction}

The fast evolution of the ICT has stimulated globalisation processes increasing the urge of mastering foreign languages in professional and private life spheres. Fortunately, as Blake (1998) observed, "technology can play an important role in fostering second language acquisition by electronically increasing learners' contact with a wide array of authentic materials” (p. 210). The digital revolution has, hence, benefited FL learners with a wide variety of multimedia and interactive opportunities for language learning and practice.

Moreover, online video and audio conferencing tools are especially beneficial as they increase learners' contact with expert users of the target language to enhance FL skills beyond cultural and geographical boundaries, offering the learner an experience close to face-to-face communication (Cappellini \& Rivens Mompean, 2015; Satar, 2016). In this line, Alonso-Belmonte and Vinagre (2017) state that "integrating telecollaboration practices in the L2 classroom becomes particularly relevant in a globalised world in which individuals are expected not only to show awareness of cultural differences but also to have the necessary skills to perform appropriately in different communicative settings” (p. 2).

Studies supporting the benefits of VE in skills development and employability are almost as numerous as studies reporting difficulties and challenges. Following the work by Helm (2015), we extracted a collection of lights and shadows (Fondo \& Jacobetty, 2019) in VE. Aligned with Helm's (2015) findings, results in our study showed that problems in VE were related to learners' lack of autonomy, lack of good project design and tasks, insufficient institutional support for teachers, and lack of support to learners during the projects. In addition, students reported emotional factors, such as language anxiety, as a potential problem in VE practices. Thus, we considered necessary to provide practitioners with a tool to measure and explore the anxiety experienced by learners in VE, the T-FLAS.

In this article, we will first analyse the advantages brought by the internet in FL learning and how learners can be challenged by different factors such as emotional barriers such as FLA. The process of construction of the T-FLAS is explained in the methodology section followed by the results obtained in the process of the validation of the scale. Reflections on the results and some recommendations for the application of the T-FLAS are shared in the discussion section. We finally conclude the article by giving some guidelines for future work. 


\title{
2. Background
}

\subsection{VES}

According to Blake (2016), videoconferencing has become the norm for most telecollaboration projects, tandem learning experiments, and social media exchanges (Lin, Warschauer, \& Blake, 2016).

\begin{abstract}
"More recent studies have investigated the contributions of the webcam in videoconferencing environments and [how] the interlocutor's image [...] gives access to communicative resources including gestures, facial expressions, body movements and gaze, what may contribute to more active communication and better mutual understanding” (Cohen \& Wigham, 2019, p. 2).
\end{abstract}

However, in order to provide students with meaningful and enjoyable VE projects through videoconferencing, it is necessary to explore the students' perceptions of this environment.

In 2015, SpeaQ With Me (SWM)3, an online platform for FL speaking practice, was created by two master students at the University of Saarland. The project was supported by the German federal grant EXIST gründerstipendium as a university spin-off startup. SWM was a free web-based platform that provided FL learners with a community of learners, a videoconferencing tool, a text chat, communicative tasks with language support, and a dictionary. The study carried out (Fondo, Carroll, $\&$ Faber, 2017) showed that the SWM platform, despite having 2,040 registered learners, had very low activity, especially regarding video chat use. From the 2,040 members, 83 did not use the platform after registering, 1,879 used the text chat exclusively and only 78 used the video chat. The study also showed that while a vast majority of the participants (70\%) expressed that they did not engage in speaking via video chat because they could not find a partner, $40 \%$ of the participants reported emotional barriers in the use of the video chat expressing that they did not use the tool because they felt too shy. The platform finally closed at the end of 2017 as a result of the low activity and lack of funding.

The results in the study highlight the importance of providing students with sufficient support in VE but also the presence of emotional barriers in which FLA could be present. This was the motivation to deeply explore FLA in VE and to tailor a scale to measure FLA in VE environments, the T-FLAS. The scale is designed to be applicable to any telecollaborative/VE context in which FL

3. http://speaqwithme.blogspot.com/2017/02/how-to-speaq-with-me-find-conversation.html 
learning and speaking practice are involved. Initially, the scale was named the E-Tandem FLA Scale (ETFLAS) because it was designed and tested in e-tandem projects based on bilingual language exchanges (Brammerts, 2001). However, subsequent applications of the scale in telecollaborative projects beyond language practice motivated the evolution of the name to T-FLAS. The use of the term telecollaboration to rename the questionnaire was preferred among other terms under the umbrella of VE as it entails intercultural online interaction in the FL (Van der Velden, Millner, \& Van der Heijden, 2016); the contextual environment in which the scale can be administered.

\subsection{FLA}

FLA, a term coined by Horwitz, Horwitz, and Cope in 1986, is a dysphoric and situational anxiety with inhibiting and debilitating effects on the learners. The effects of FLA on learners have been researched since the early 1970's, even before the term was coined in 1986, in studies as Chastain (1975), Kleinmann (1977), and Scovel (1978), among others. Since then, a large number of studies have addressed the effects of FLA on learners. In 1991, MacIntyre and Gardner supported the claim by Horwitz et al. (1986) that FLA was a situational anxiety independent to other types of anxiety with negative effects on learning. They also found FLA to be one of the best predictors of success in FL learning (Gardner \& MacIntyre, 1993; MacIntyre \& Gardner, 1991).

Moreover, FLA has been related to willingness to communicate as learners suffering from FLA tend to avoid communication in the FL. For instance, Liu and Jackson (2008) investigated the relationship between Chinese university English FL students' unwillingness to communicate in English and their FLA, and found the two variables to be closely related. Horwitz, Tallon, and Luo (2010) argue that, indeed, the construct willingness to communicate is an alternative conceptualisation of FLA. Liu and Huang (2011) found that anxiety and students' English learning motivation were significantly negatively correlated. In fact, according to, Bailey, Onwuegbuzie, and Daley (2003), FLA provokes students' attrition and withdrawal. In summary, FLA is very significant because of its potential negative effects at a cognitive, social, and personal level (Tallon, 2006). For instance, subjects suffering from FLA show communication avoidance, problems with performance, achievement and learning, and high levels of self-consciousness (Luo, 2014).

Factors provoking FLA are many and stem from different sources, but predominantly from the difficulty of students presenting themselves and establishing authentic social interaction in the FL. As Horwitz, Horwitz, and Cope (1991) state, "probably no other field of study implicates self-concept and self-expression to the degree that language study does" (p. 31). This view is reinforced by Horwitz (2017) who states that she has argued repeatedly in many of her studies 
that some "people experience anxiety in language learning because of distress at their inability to be themselves and to connect authentically with other people through the limitation of the new language” (p. 41).

According to Moor (2007), FLA may also occur due to cultural differences and not only to FL use. Culture shock or anxieties associated with immersion in new cultures have long been recognised (Yan \& Horwitz, 2008). Indeed, FLA is not context-free, but context-dependent (Kim, 2010) and it might vary in different cultural groups or instructional contexts (Kim, 2010; Kunt, 1997).

FLA can also be technology-dependent when online communication tools and their affordances shape the interaction. In this regard, McNeil's (2014) study explored the anxiety created by oral asynchronous computer-mediated communication and found that the fact of communicating asynchronously does not eliminate FLA, highlighting the importance of including learners' abilities, the environment and tasks in the study of FLA. On the other hand, Di Gennaro and Di Villarroel's (2019) study analysed the effects of synchronous oral communication and reported that although learners in their telecollaboration project felt "less [intimidated] corresponding with peers of the target language than in a professor-student classroom setting” (p. 172), they raised concerns in relation to the "psychological compulsion created by the immediacy of the synchronous video communication” (p. 171). The interlocutors' first language can also be a source of FLA as in Jauregi and Melchor-Couto's (2017) study in which secondary school level students experienced higher levels of FLA when interacting with Native Speakers (NSs) compared to those interacting with NonNative Speakers (NNSs) through videoconferencing technologies.

While VE may elicit anxiety, it can also have benefits on FLA. For instance, Appel and Gilabert (2002), described learning in e-tandem as a method that "encourages familiarity and solidarity, reduces anxiety and, over time, increases confidence” (p. 18). This aligns with the perception of Colombian students who expected e-tandems to reduce their fears of speaking and increase their self-confidence when using the FL (El-Hariri \& Jung, 2015). El-Hariri (2017) also reports that e-tandem had a positive effect on reducing FLA among students explaining that the lower levels of FLA in the study resulted from carrying out speaking practice in a different environment than the traditional teacherclassroom; similar to the aforementioned findings in Di Gennaro and Di Villarroel (2019). However, so far, research on VE has focused more on the affective factors involved in online interaction between two subjects and their effect on students' motivation than on FLA (Di Gennaro \& Di Villarroel, 2019). The impact of VE on FLA and vice-versa can result in negative learning experiences. In this regard, the T-FLAS will serve as a tool to explore FLA in VE settings. The foundations and the development of the T-FLAS are explained in the next section. 


\section{Methodology}

\subsection{Context and participants}

The present study is based on two projects which ran simultaneously, following the same structure and data gathering procedure. In both projects, the VE was a nine-week project using Zoom ${ }^{4}$, a videoconferencing tool that allows recording online meetings directly in the cloud. The students participated in the project on a voluntary basis which was rewarded with $10 \%$ of the final grade in all the institutions involved.

The first one was a one-to-one bilingual exchange project (English/Spanish for international business) that was designed for Spanish-speaking undergraduate students taking the international management subject within the business degree at Universitat Oberta de Catalunya (UOC) located in Barcelona (Spain). Due to the unbalanced number of Spanish versus English speakers, undergraduate students at Benemérita Universidad Autónoma de Puebla (BUAP) in Mexico were incorporated into the project. The English speakers were undergraduate students studying Spanish for professional purposes at the University of Minnesota (UMN), University of Maryland (UMBC) and the University of Limerick (UL). Students in BUAP, UMN, UMBC, and UL were 19 to 21 years old, whereas in UOC they were between 25 to 50 years old. Anglophone participants had levels of Spanish between B1 and B2. Students at BUAP and UOC had an English proficiency level between B1 and C1.

Ten different communicative tasks were designed to support students' conversation during the videoconferencing sessions. Each session had a different task type and in every session students carried out one task in English and one task in Spanish which were complemented with additional questions for intercultural reflection in both target languages. Their first encounter was an icebreaking session based on a free-talk task. The subsequent four sessions had, in chronological order of completion, a spot the difference, problem-solving, opinion-exchange, and role-play task types.

After completing each task, students had to fill a short task evaluation questionnaire and at the end of the videoconferencing session they completed the session evaluation questionnaire with the aim of exploring some emotional aspects of their interaction in the VE. For this reason, the tasks were embedded in Limesurvey (Figure 1 and Figure 2).

4. zoom.us 
Figure 1. Task sample embedded in Limesurvey

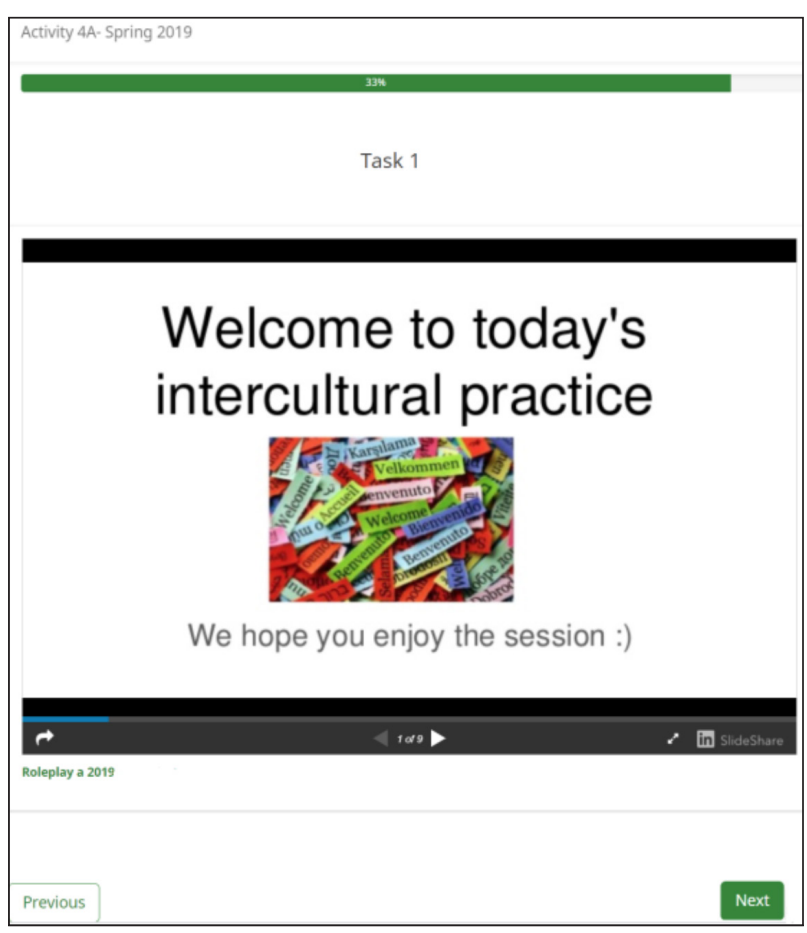

Figure 2. Post-task questionnaire

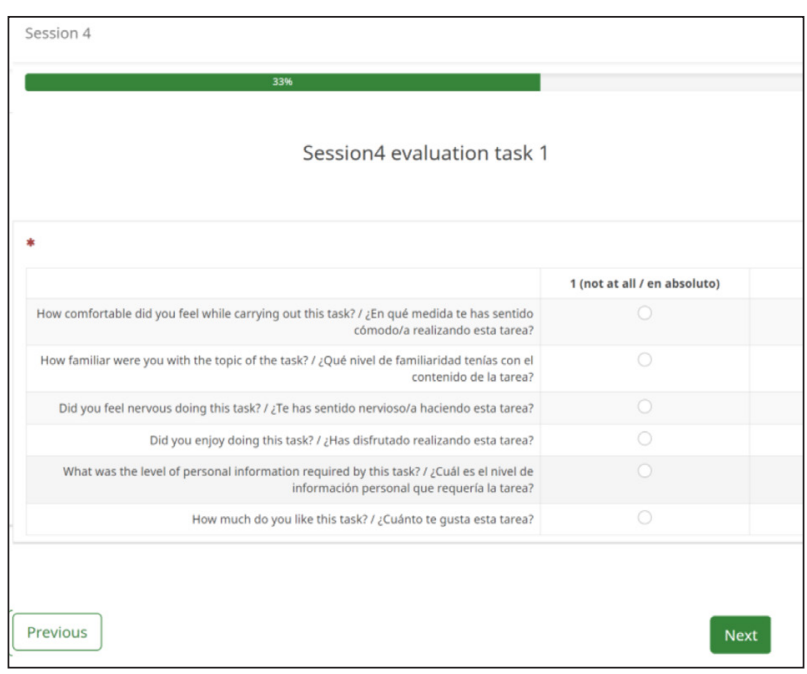


The other parallel project was a one-to-many monolingual exchange project in English as a lingua franca with 25 undergraduate business students from BUAP (Spanish speakers) and 171 undergraduate students (English speakers) from Queens College New York (QCNY) enrolled in the statistics subject in the degree in economics (Table 1). Both parallel projects differed because QCNY students did not aim to carry out speaking practice but real-world based practice for their statistics subject and development of 21st-century skills for employability (Fondo \& Withanachchi, 2019). The tasks in this project were only in English and part of the original content designed for the Spanish-English exchange project was adapted to the statistics subject curriculum. The Mexican students had the same content (same topics) as Spanish students from UOC, but the task type was always opinion-exchange. Finally, as NY students communicated only in their native language during the project, the T-FLAS was adapted for them and a new version based on intercultural issues was designed, the E-Tandem Intercultural Anxiety Scale (ETICAS). However, the data gathered through the ETICAS have not been used in the present study.

\section{Table 1. Students' participation rates}

\begin{tabular}{|c|c|c|c|c|c|c|c|}
\hline \multirow{3}{*}{$\begin{array}{l}\text { Type of project } \\
\text { Bilingual } \\
\text { One-on-one }\end{array}$} & \multirow{2}{*}{$\begin{array}{l}\text { Institution } \\
\text { University }\end{array}$} & \multirow{2}{*}{$\begin{array}{l}\text { Sample } \\
\text { Enrolled }\end{array}$} & \multicolumn{2}{|l|}{ Gender } & \multicolumn{3}{|c|}{ Participation } \\
\hline & & & Female & Male & Active & Inactive & Drop-out \\
\hline & BUAP & 2 & 1 & 1 & 2 & 0 & 0 \\
\hline & UL & 19 & 8 & 11 & 17 & 2 & 1 \\
\hline & UMN & 22 & 10 & 12 & 20 & 2 & 0 \\
\hline & UMBC & 6 & 4 & 2 & 3 & 3 & 1 \\
\hline & UOC & 40 & 21 & 19 & 30 & 10 & 0 \\
\hline & Total & 89 & 44 & 45 & 72 & 17 & 2 \\
\hline \multirow{3}{*}{$\begin{array}{l}\text { Monolingual } \\
\text { One-to-many }\end{array}$} & QCNY & 171 & 69 & 102 & 147 & 24 & 21 \\
\hline & BUAP & 25 & 12 & 13 & 23 & 2 & 2 \\
\hline & Total & 196 & 81 & 115 & 170 & 26 & 23 \\
\hline
\end{tabular}

\subsection{The T-FLAS}

The T-FLAS is a 21-item scale with a one to five Likert scale developed in English and Spanish. The questionnaire addresses problems with technology (seven items) and FLA (14 items) in VE contexts. The 14 items about FLA are based on the original Foreign Language Classroom Anxiety Scale (FLCAS) by Horwitz et al. (1986) and its renewed and culturally adapted version by Al-Saraj (2014) which highlights social aspects of the FLA. Indeed, the FLCAS has been translated into different languages and adapted to different learning cultures and purposes (See for instance Aida, 1994; Al-Saraj, 
2014; Panayides \& Walker, 2013; Pérez Paredes \& Martínez Sánchez, 2001; Tóth, 2008); as well as to different learning contexts such as online environments (Arnold, 2007; Baralt \& Gurzynski-Weiss, 2011) and written practices (Cheng, Horwitz, \& Schallert, 1999). The reliability and consistency of the FLCAS questionnaire have been widely analysed and defended by a great number of studies. For instance, De la Morena, Burón, and Fernández-Martín (2011) and Panayides and Walker (2013) carried out psychometric studies of the questionnaire with very positive results.

The original scale by Horwitz et al. (1986), as well as the version created by Al-Saraj (2014), contended 33 items. In the adaptation made for the T-FLAS, some items were discharged because they were not relevant for the VE context as they refer to in-class dynamics and actions such as being called by the teacher or taking exams (please see the Appendix 1 to see the items included and discharged in the T-FLAS). The decision to reduce the number of items also aimed to avoid a lengthy questionnaire as it was originally designed to be administered online so control over questionnaire completion was reduced and lengthy scales can "result in an extended time to survey completion, a greater amount of missing data and lower response rates. They also may increase random or systematic error associated with fatigue or boredom” (Maloney, Grawitch, \& Barber, 2011, p. 162).

The T-FLAS has been piloted in two rounds. The first pilot study delivered the questionnaire online as a Google Form sent by email to a total sample of 243 people to explore the internal consistency and dimensions of the questionnaire to identify problems and inform future improvements. The sample was chosen among personal and professional contacts of the researchers aiming to reach a wider range of ages and professional profiles. The total response was 36 out to 243, a 14\% response rate. For the second piloting round (Fondo \& Erdocia, 2018), the questionnaire items were revised by a group of eight experts from linguistics, computer science, e-learning, psychology, and sociology to refine the items' wording and adequacy. As a result, the initial 18 items T-FLAS was enlarged to 21 items: three items were added (Items 6, 12, and 16) regarding online interaction and the partner's proficiency effect (see Appendix 1).

In this study, the T-FLAS was administered online as part of the project evaluation questionnaire after all the students had completed their participation in the project. Students used a participant code to anonymise their data during the data gathering process.

\subsection{Data analysis}

The final version of the T-FLAS, the 21-item scale, obtained positive internal consistency reliability with a 0.96 Cronbach's alpha coefficient. The data gathered in the study was analysed to explore 
the components of the T-FLAS through a factor analysis followed by a clustering of the sample in order to identify the profiles of students regarding anxiety in VE as explained in the following subsections.

\subsubsection{Principle Component Analysis (PCA)}

We performed a PCA analysis dimension reduction technique (Abdi, 2003) on the 21 T-FLAS items using the varimax orthogonal rotation method which minimises the number of variables that have high loadings on each factor, simplifying the interpretation of the factors (Kaiser, 1958). The analysis was performed using the R programming language (version 3.4.0) and the principal components analysis ('principal') function of the Procedures for Psychological, Psychometric, and Personality Research ('psych') R package (version 1.8.4). The used sample, participants using the FL in the projects (Table 1), was adequate for PCA - the overall Kaiser-Meyer-Olkin (KMO) measure of sample adequacy was 0.91 and the minimum item-level KMO was 0.78 .

\subsubsection{Clustering of the sample}

The resulting PCA score variables were used to create clusters to identify profiles of students. Cluster analysis or clustering is the task of grouping a set of objects so objects in the same group, called a cluster, are more similar to each other than to those in other groups or clusters (Romesburg, 1984). Cluster analysis itself is not one specific algorithm and can be achieved by various algorithms. As a means to obtain reliable results in the number of indices, clustering was calculated with the help of several indices for determining the optimal number of clusters, such as Hartigan (Hartigan, 1975), TrCovW and TraceW (Milligan \& Cooper, 1985), Rubin (Friedman \& Rubin, 1967), Cindex (Hubert \& Levin, 1976), Ratkowsky (Ratkowsky \& Lance, 1978), the SD index (Halkidi, Vazirgiannis, \& Batistakis, 2000), and D Index (Lebart, Morineau, \& Piron, 2000) presented in Figure 5 as an example of a graphical method of determining the number of clusters. In addition, clusters were calculated using hierarchical clustering (Figure 5) with Ward's (1963) method. For further information about clustering methods in 'R' please see Charrad, Ghazzali, Boiteau, and Niknafs (2014).

\section{4. $\quad$ Results}

The results obtained from the analysis above are presented in this section which, in conjunction, will allow a better understanding of the sources of anxiety in VE settings. The results will inform on 
the main anxiety factors in VE resulting from the PCA and provide the profiles of learners resulting from clustering the sample using the T-FLAS’ PCA.

\subsection{PCA results: T-FLAS items organised by dimensions}

The PCA indicated that three factors of the T-FLAS had an eigenvalue greater than one (Figure 3), which is the rule of thumb for identifying the number of factors. However, we decided to retain the fourth factor (with an eigenvalue close to one) because the division of items by factors was more conceptually coherent and the total percentage of explained variance was $77 \%$.

Figure 3. Scree plot of component eigenvalues

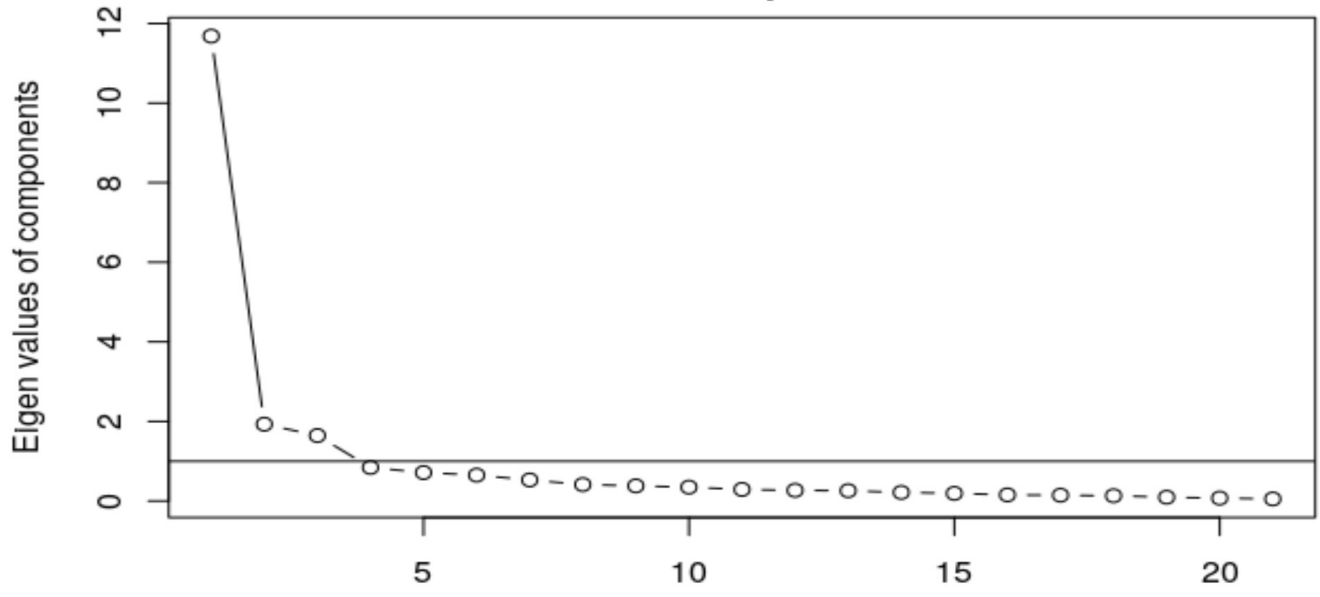

We measured the reliability of the resulting constructs (variable groupings by their association each principal component) using the Cronbach’s $(1947,1951)$ alpha (a) measure of internal consistency. The generally agreed-upon lower limit of acceptability is 0.70 , even though in exploratory research it may decrease to 0.60 (Hair, Black, Babin, \& Anderson, 2014). The identified constructs (grouping of variables according to its higher loading in the components) had acceptable reliability statistics: a ranged between 0.76 and 0.96 . More details about the PCA can be found in Table 2 .

The results of the PCA indicated that the two first components of the T-FLAS are related to the linguistic and learning components of FL e-tandem practices. The first component was associated with feelings of anxiety related to FL speaking practices in VE settings. We named this component 
communication apprehension, the name of a dimension that was identified in several studies about the original FLCAS (Al-Saraj, 2014; De la Morena et al., 2011; Liu \& Huang, 2011; Tóth, 2008). The second component was associated with situations associated with FL learning settings in e-tandem settings. We named it anxiety in the learning processes and situation, another dimension found in FLCAS studies (Al-Saraj, 2014; De la Morena et al., 2011). The items associated with the other components are specific to the virtual environments that characterise VE practices. For instance, the third component was associated with anxiety related to online interaction and videoconferencing, and was named online interaction anxiety. The fourth and final component was related to more general aversion towards digital technology; thus we named it technophobia. (Please, see Appendix 2 for a comparative example of studies and dimensions).

\section{Table 2. T-FLAS items organised by dimensions resulted from a PCA}

\begin{tabular}{|c|c|c|}
\hline Principal components & Items & Loadings \\
\hline \multirow{2}{*}{$\begin{array}{l}\text { Dimension } 1 \\
\text { Communicative } \\
\text { apprehension }\end{array}$} & $\begin{array}{l}\text { [21] "I feel anxious when I want to say something but can't find the proper } \\
\text { words to say it in the foreign language during the e-tandem speaking practice" }\end{array}$ & 0.846 \\
\hline & [19] "In e-tandem language practice I can get so nervous I forget things I know" & 0.789 \\
\hline \multirow[t]{8}{*}{ Cronbach 0.95} & $\begin{array}{l}\text { [9] "I am nervous speaking the foreign language in front } \\
\text { of native speakers during e-tandem practice" }\end{array}$ & 0.768 \\
\hline & $\begin{array}{l}\text { [13] "I feel overwhelmed by the number of grammatical } \\
\text { rules I have to learn in the foreign language" }\end{array}$ & 0.759 \\
\hline & $\begin{array}{l}\text { [11] "I feel nervous when talking in the foreign language } \\
\text { to someone I just met for e-tandem practice" }\end{array}$ & 0.746 \\
\hline & $\begin{array}{l}\text { [8] "During e-tandem language exchange I feel nervous when } \\
\text { I can’t express myself in the foreign language" }\end{array}$ & 0.712 \\
\hline & $\begin{array}{l}\text { [15] "I feel low self-confidence about speaking the } \\
\text { foreign language during e-tandem sessions" }\end{array}$ & 0.655 \\
\hline & $\begin{array}{l}\text { [20] "I feel anxious when I don’t understand what my } \\
\text { e-tandem partner is saying in the foreign language" }\end{array}$ & 0.647 \\
\hline & $\begin{array}{l}\text { [16] "I feel nervous talking to an e-tandem partner who has a } \\
\text { higher level of proficiency in the foreign language than me" }\end{array}$ & 0.645 \\
\hline & $\begin{array}{l}\text { [10] "I feel uncomfortable in speaking a foreign } \\
\text { language with my e-tandem partner" }\end{array}$ & 0.554 \\
\hline \multirow{5}{*}{$\begin{array}{l}\text { Dimension } 2 \\
\text { Anxiety in the learning } \\
\text { processes and situation }\end{array}$} & [7] "I don’t enjoy talking about my private life online" & 0.887 \\
\hline & [18] "I feel anxious when learning a foreign language" & 0.858 \\
\hline & $\begin{array}{l}\text { [12] "I feel nervous talking to an e-tandem partner who has a } \\
\text { lower level of proficiency in the foreign language than me" }\end{array}$ & 0.806 \\
\hline & [14] "I fear pronouncing words incorrectly in my e-tandem speaking practice” & 0.689 \\
\hline & $\begin{array}{l}\text { [17] "I feel nervous when I am around more experienced } \\
\text { foreign language users in e-tandem practices" }\end{array}$ & 0.625 \\
\hline
\end{tabular}




\begin{tabular}{|c|c|c|}
\hline \multirow{2}{*}{$\begin{array}{l}\text { Dimension } 3 \\
\text { Online interaction }\end{array}$} & [6] "I feel uncomfortable interacting online" & 0.778 \\
\hline & [3] “I don’t like to talk online to new people” & 0.67 \\
\hline \multirow[t]{2}{*}{ Cronbach 0.83} & [4] "I feel uncomfortable in video conferences" & 0.635 \\
\hline & $\begin{array}{l}\text { [5] "I get very nervous when I have problems with } \\
\text { technology during video conferences" }\end{array}$ & 0.629 \\
\hline \multirow{2}{*}{$\begin{array}{l}\text { Dimension } 4 \\
\text { Technophobia }\end{array}$} & [1] “I don’t like using technological devices” & 0.879 \\
\hline & [2] "I feel uncomfortable learning online” & 0.781 \\
\hline
\end{tabular}

\subsection{Cluster analysis}

The resulting four PCA scores variables were then used to create clusters to identify profiles of the discovered T-FLAS dimensions (the four components). The number of clusters was calculated with the help of several indices for determining the optimal number of clusters. They suggested that four was the optimal number of clusters for partitioning the cases using the factor scores of the PCA. In other words, the number of clusters in our sample was based on how strongly items on the scale are associated with each factor or dimension in the factor score coefficient matrix. Hence, each cluster is related to the dimensions of the PCA as explained below (Figure 6 and Figure 7).

Figure 4. Determination of the optimal number of clusters by $D$ Index values
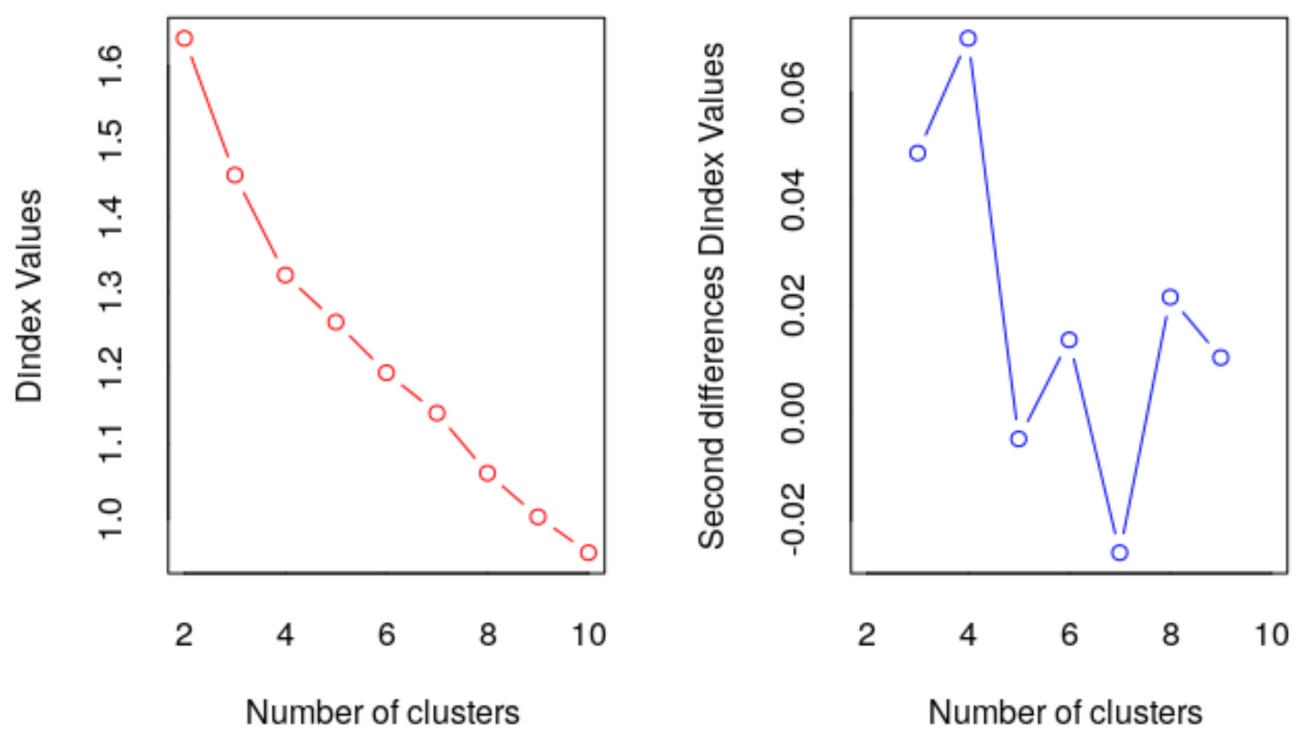
The choice of four clusters is also visible in the dendrogram that portrays the distances between clusters or individuals, the Ward's (1963) hierarchical clustering method (Figure 5).

Figure 5. Dendogram with hierarchical clustering using Ward's (1963) method

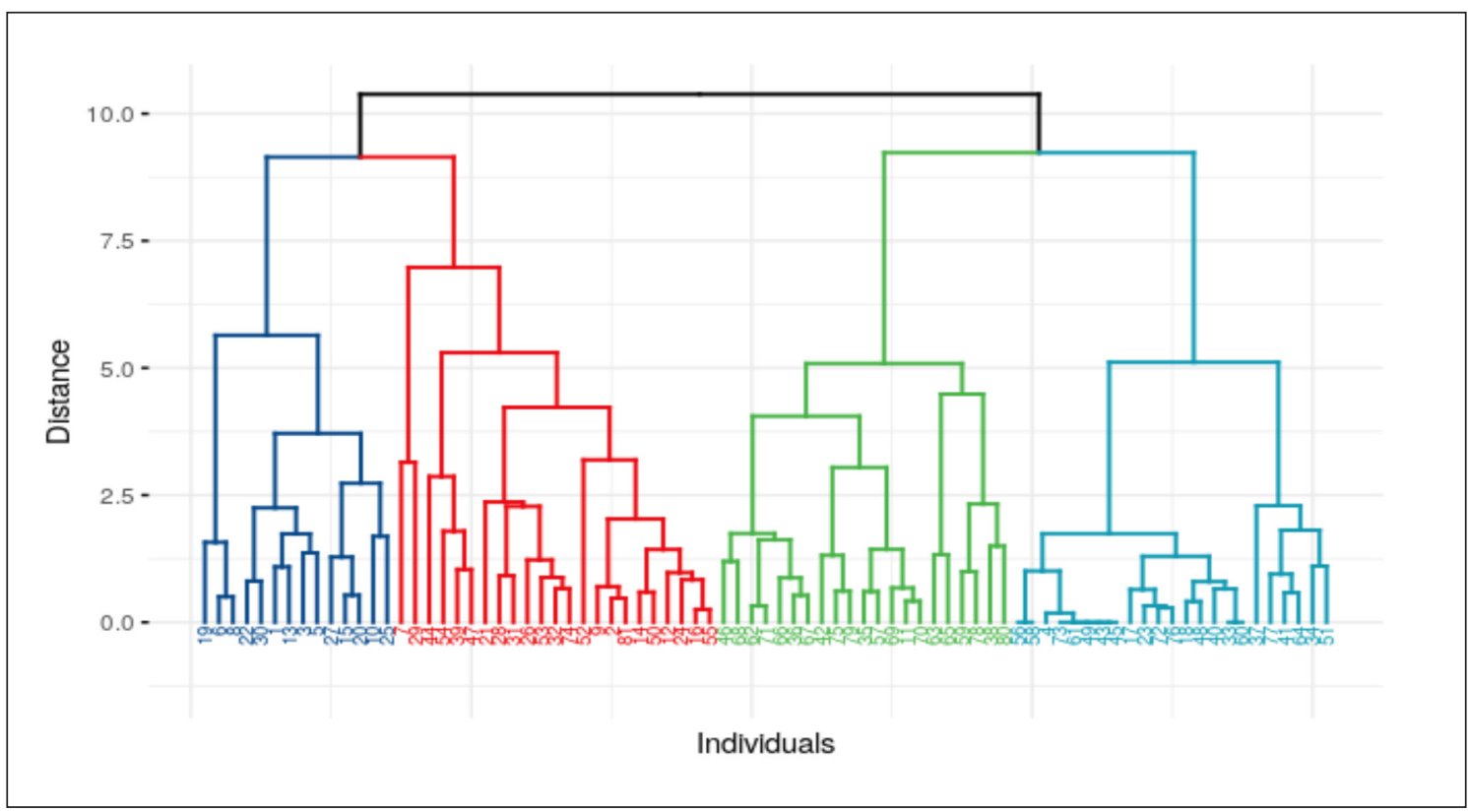

We also tried to name the identified clusters by analysing the PCA scores distributions in each cluster. The first resulting cluster (Cluster 1) shows marked differences in the first communicative apprehension (Figure 6 - left) component scores but low values in the other three dimensions. This led us to name Cluster 1 as apprehensive communicators. Cluster 4 clearly expresses higher levels of anxiety in the learning processes and situations (Figure 6 - right) with lower levels in the other dimensions so it was identified as anxious learners.

In terms of online interaction anxiety, Cluster 2 seems to be associated with relatively higher anxiety levels. The same cluster is also associated with higher levels of technophobia (Figure 7) so we named Cluster 2 technophobes. Since Cluster 3 tends to express low levels of anxiety in all the dimensions, it was named confident communicators and learners. In addition, results show that only $28 \%$ of the sample fell into Cluster 3 . Hence, the other $72 \%$ of the students present some type of anxiety (Table 3). 
Figure 6. Linguistic and learning components of FL e-tandem practices
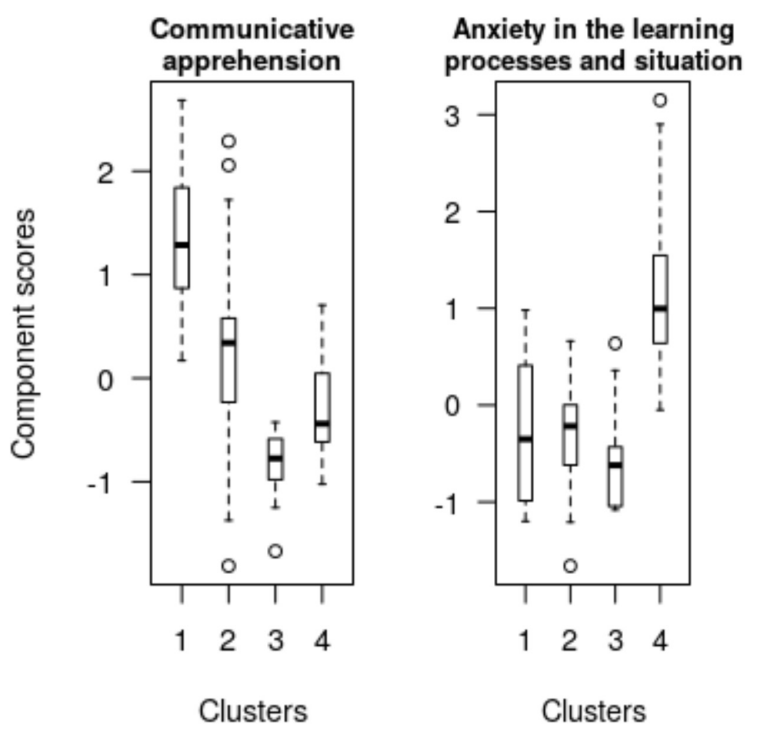

Figure 7. Virtual environments components
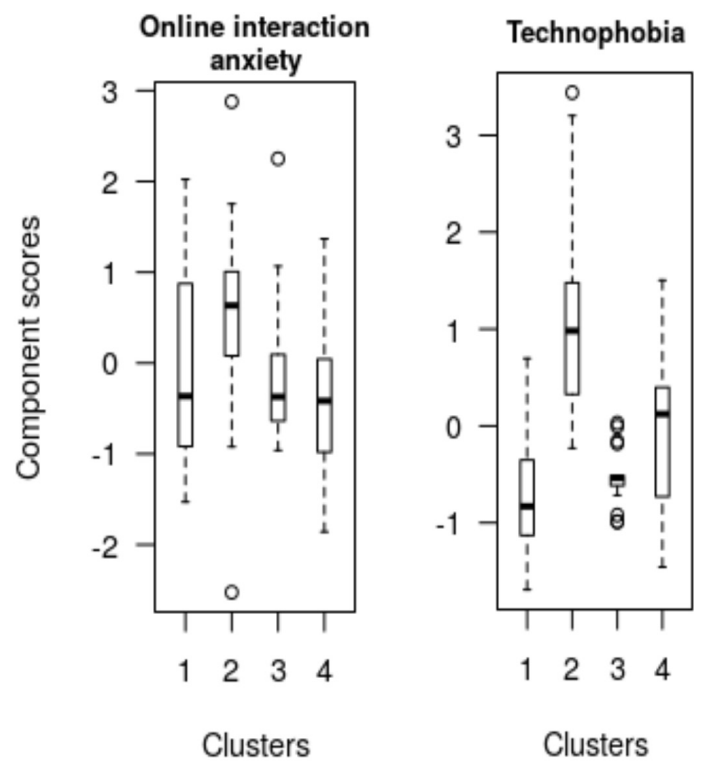
Table 3. T-FLAS Cluster frequencies

\begin{tabular}{|l|l|l|}
\hline Cluster & n & $\%$ \\
\hline 1 - Apprehensive communicators & 14 & $17 \%$ \\
\hline 2 - Technophobes & 23 & $28 \%$ \\
\hline 3 - Confident communicators and learners & 23 & $28 \%$ \\
\hline 4 - Anxious learners & 21 & $26 \%$ \\
\hline Total & 81 & $100 \%$ \\
\hline
\end{tabular}

\section{Discussion, limitations, and implications}

The findings in the study suggest that the anxiety suffered by participants in VE practices has four components that can be divided into two main aspects: (1) FL expression and learning, and (2) virtual environments. Thus, linguistic and learning-related sources of anxiety in VE practices can be described as communication apprehension and anxiety in the learning processes and situation, which are not specific to VE settings but to FL learning in general. Indeed, FL learning processes (Horwitz et al., 2010) and communication apprehension (Bailey et al., 2003) are also present in studies based on face-to-face learning settings.

The resulting dimensions of online interaction anxiety and the more general technophobia, indicate that virtual environments can also be a source of anxiety. Results suggest "that participants need to know how communication technologies function in order to interpret delays in communication, overlaps (in synchronous interaction), and late responses. This aspect also encompasses that participants need to [be familiar with] the affordances and constraints of the technologies being used" (Alonso-Belmonte \& Vinagre, 2017, p. 344). Indeed, different problems related to technology emerged during the project because participants were asked to communicate through Zoom (a tool they were not familiar with) for data collection purposes. In the subsequent edition, which took place in the spring semester of 2019, students were given the freedom to choose the videoconferencing tool, and more familiar tools such as Skype and WhatsApp were the most used, leaving Zoom in the last position (Fondo, Lamolla, Withanachchi, \& Arnold, in press). As a result, anxiety levels in the dimensions related to technology were higher in 2018 than in 2019. It is possible then that a certain amount of students' anxiety related to technology was caused by the usage of a tool which was not of their choice.

We also identified four profiles of students using the T-FLAS dimensions to define the clusters of our sample. Two of these profiles are related to $\mathrm{FL}$ communication and learning: apprehensive 
communicators and anxious learners, while the technophobes profile is related to unease around technological devices and their usage. The last profile presented low levels of overall anxiety so was named as confident communicators and learners. It should be taken into account that the original FLCAS is a context-dependent questionnaire. As a result, factor analysis carried out with different samples has normally driven to a different number and types of dimensions (Appendix 2). This context sensibility can also affect the T-FLAS, so new dimensions can emerge in different contexts with different samples and result in new and different clusters. This could be a limitation, as using pre-established profiles can provide inconsistent results. However, it also allows for more tailored research and comparison between different samples and contexts.

The specificity of the tool also presents a limitation as it cannot be administered if the subjects have not been involved in a VE before. Hence, studies based on pre-post test designs will not be possible in that case. However, it can be administered after the first exchange and at the end of the project. Moreover, the administration of the questionnaire after students' first encounter can help project coordinators to detect students experiencing problems and anxiety and provide them with some extra support.

The novelty of the T-FLAS makes it difficult to propose best practices regarding emotional barriers in VEs. However, the T-FLAS has been administered in four different projects (see for instance, Fondo et al., in press). From the results of these projects, it can be extracted that the main problems in VEs normally stem from anxiety related to online interaction regarding social interaction and self-consciousness when communicating in and using the FL (Items 13, 14, 16, 18, 20, and 21 had higher values in all the studies). However, interacting online seems not to be a problem, only if it is with a stranger (Item 11). Although technophobia does not appear as a relevant barrier for learners, all the studies showed that experiencing technical problems is a source of anxiety for students (Item 5).

These first exploratory findings can set the starting point for future research and serve as embryonic guidance for practitioners. For instance, it should be preferred to avoid taking risks with new communication tools if the students are not familiar with them or the tools are not very reliable yet. In addition, tutorials or instructions on how to use the tools can reduce anxiety stemming from this dimension. In the case of apprehensive communicators and anxious learners, it will be recommended to scaffold the online interaction with initial contact with partners by email, previous (in-class) preparation of the topics, and good task design. Clear information about the project, explaining objectives and procedures with explicit and constant support from coordinators and teachers will also help to reduce uncertainty and fears stemming from working autonomously. 


\section{Conclusion}

The interest of scholars in improving learners' experiences in VE is unarguable. Their efforts to understand difficulties in these environments and to provide solutions to practitioners are clearly reflected by a large number of studies and initiatives in the field (see for instance Helm, 2015; O'Dowd, 2018). So far, researchers and practitioners in VE have explored difficulties regarding language (Vinagre \& Muñoz, 2011), cultural factors (Kramsch, 2014), and task design (Müller-Hartmann, 2016). However, research on the emotional dimension of VE is not very extensive, and appropriate tools that enable researchers to measure quantitatively the emotional dimensions particular to VE contexts do not exist.

Having the possibility of measuring FLA in VE provides an easy and quick way to check how students are feeling or felt during the exchange in order to detect problems during the project and analyse the results of the project. The experience in this study is that anxious students are not willing to share their feelings in a closer manner as none of the high anxious students wanted to take part in the interviews. Thus, it is very unlikely that students will contact the coordinators or teachers to report anxiety episodes and emotional problems. It should be noted that students experiencing FLA normally present high levels of self-consciousness (Horwitz et al., 1986) that will probably prevent them from exposing themselves and voluntarily sharing their feelings. In this regard, a questionnaire such as the T-FLAS seems to be more emotionally aseptic as students express their feelings individually, just indicating the levels on a Likert scale. Nevertheless, quantitative methods provide limited information about the events as they narrow down reality to a certain number of causes and effects and do not allow the emergence of new variables. Hence, the use of the T-FLAS alone will not be enough to explain the reasons and results of the presence of FLA in VEs. It will be necessary to include complementary data from qualitative methods with a more holistic approach (Imai, 2010).

The fact that only $28 \%$ of students in the study belonged to the group of confident communicators and learners (Cluster 3 - Table 3) highlights the importance of deepening into FLA in VE environments. FLA causes and effects in VE remain unclear. More research is needed to provide practitioners with a collection of best practices for project design and coordination. Future research in emotional factors involved in VE can be guided by previous research on FLA. Thus, the T-FLAS can be used to explore, among others, the relationship of FLA with students' profiles and oral performance (Gregersen \& Horwitz, 2002), withdrawal and attrition (Bailey et al., 2003), or the effect of the type of task and type of interaction (Baralt \& Gurzynski-Weiss, 2011; Brennan, 2016), as well as technology (Arnold, 2007; Aydin, 2018) and enjoyment on students' FLA levels during interaction and along the project (Dewaele \& MacIntyre, 2014). 
However, it seems that in VE there is a tendency to carry out research and VE projects as stand-alone initiatives. As O’Dowd (2018) explains; “over the past three decades, approaches to virtual exchange have evolved in different contexts and different areas of education, and these approaches have happened, to a great extent, in blissful isolation of one another” (p. 2). In this regard, we hope that providing a research tool specifically designed for this environment as the T-FLAS could contribute to open a line of research in the field and to foster research cohesion.

\section{Acknowledgements}

We would like to express our gratitude to all the professors at UMN, UL, BUAP, UMBC, and QCNY for their participation in the project. We would also like to thank the reviewers and editors for their extremely meaningful contributions to this article and help, we will always be indebted to them.

\section{References}

Abdi, H. (2003). Multivariate analysis. In M. Lewis-Beck, A. Bryman, T. Futing (Eds), Encyclopedia for research methods for the social sciences (pp. 699-702). Sage.

Aida, Y. (1994). Examination of Horwitz, Horwitz, and Cope's construct of foreign language anxiety: the case of students of Japanese. The Modern Language Journal, 78(2), 155-168.

Alonso-Belmonte, I., \& Vinagre, M. (2017). Interculturality and identity in computer-mediated communication: findings from L2 teaching contexts. Computer Assisted Language Learning, 30(5), 343-350.

Al-Saraj, T. M. (2014). Revisiting the foreign language classroom anxiety scale (FLCAS): the anxiety of female English language learners in Saudi Arabia. L2 Journal, 6(1), 50-76.

Appel, C., \& Gilabert, R. (2002). Motivation and task performance in a task-based web-based tandem project. ReCALL, 14(1), 16-31.

Arnold, N. (2007). Reducing foreign language communication apprehension with computer-mediated communication: a preliminary study. System, 35(4), 469-486.

Aydin, S. (2018). Technology and foreign language anxiety: implications for practice and future research. Journal of Language and Linguistic Studies, 14, 193-211.

Bailey, P., Onwuegbuzie, A. J., \& Daley, C. E. (2003). Foreign language anxiety and student attrition. Academic Exchange Quarterly, 7(2), 304-309.

Baralt, M., \& Gurzynski-Weiss, L. (2011). Comparing learners’ state anxiety during task-based interaction in computermediated and face-to-face communication. Language Teaching Research, 15(2), 201-229.

Blake, R. (1998). The role of technology in second language learning. In H. Byrnes (Ed.), Learning foreign and second languages: perspectives in research and scholarship (pp. 209-237). Modern Language Association. 
Blake, R. (2016). Technology and the four skills. Language Learning \& Technology, 20(2), 129-142.

Brammerts, H. (2001). Autonomes Sprachenlernen im Tandem: Entwicklung eines Konzepts. Selbstgesteuertes Sprachenlernen im Tandem: Ein Handbuch, 2, 9-16.

Brennan, K. E. (2016). Second language anxiety and task complexity. Unpublished doctoral dissertation. University of Barcelona, Spain.

Cappellini, M., \& Rivens Mompean, A. (2015). Role taking for teletandem pairs involved in multimodal online conversation: some proposals for counselling practice. Language Learning in Higher Education, 5(1), 243-264.

Charrad, M., Ghazzali, N., Boiteau, V., \& Niknafs, A. (2014). NbClust package: finding the relevant number of clusters in a dataset. Journal of Statistical Software, 61(6), 1-36.

Chastain, K. (1975). Affective and ability factors in second language acquisition. Language Learning, 25(1), 153-161.

Cheng, Y. S., Horwitz, E. K., \& Schallert, D. L. (1999). Language anxiety: differentiating writing and speaking components. Language Learning, 49(3), 417-446. https://doi.org/10.1111/0023-8333.00095

Cohen, C., \& Wigham, C. R. (2019). A comparative study of lexical word search in an audioconferencing and a videoconferencing condition. Computer Assisted Language Learning, 32(4), 448-481.

Cronbach, L. J. (1947). Test "reliability": its meaning and determination. Psychometrika, 12, 1-16.

Cronbach, L. J. (1951). Coefficient alpha and the internal structure of tests. Psychometrika, 16, 297-334.

De la Morena, M., Burón, A. S., \& Fernández-Martín, M. P. (2011). Analysis of the psychometric properties of the FLCAS (Foreign Language Class Anxiety Scale) in Spanish students of secondary education. Edupsykhé. Revista de Psicología y Educación, 10(1).

Dewaele, J. M., \& MacIntyre, P. D. (2014). The two faces of Janus? Anxiety and enjoyment in the foreign language classroom. Studies in second language learning and teaching, 4(2), 237-274.

Di Gennaro, C. M., \& Di Villarroel, Y. E. (2019). Chile-USA: a case study of telecollaboration. International Journal of Linguistics, Literature and Translation 2(2), 163-179.

Dooly, M. (2017). Telecollaboration. In C.A. Chapelle \& S. Sauro (Eds), The handbook of technology and second language teaching and learning (pp. 169-183). John Wiley \& Sons.

El-Hariri, Y. (2017). eTandem language learning and foreign language anxiety among Colombian learners of German. Colombian Applied Linguist Journal, 19(1), 22-36.

El-Hariri, Y., \& Jung, N. (2015). Distanzen überwinden: über das Potenzial audio-visueller e-Tandems für den Deutschunterricht von Erwachsenen in Kolumbien. Zeitschrift für interkulturellen Fremdsprachenunterricht, 20(1), 106-139.

Fondo, M., Carroll, P., \& Faber, C. (2017). Affordances of task-based speaking practice in an e-tandem platform: the issue around native and non-native speakers. Proceedings of the 9th International Conference on Education and New Learning Technologies, 3-5 July, 2017, Barcelona, Spain (pp. 2009-2015).

Fondo, M., \& Erdocia, I. (2018). Exploring foreign language anxiety and self-disclosure relationships in task design for e-tandem speaking practice. In P. Taalas, J. Jalkanen, L. Bradley \& S. Thouësny (Eds), Future-proof CALL: language learning as exploration and encounters - short papers from EUROCALL 2018 (pp. 54-58). Research-publishing.net. https://doi.org/10.14705/rpnet.2018.26.812 
Fondo, M., \& Jacobetty, P. (2019). The lights and shadows of intercultural exchange projects for 21st-century skills development: analysis and comparison of two online case studies. In A. Plutino, K. Borthwick \& E. Corradini (Eds), New educational landscapes: innovative perspectives in language learning and technology (pp. 63-69). Researchpublishing.net. https://doi.org/10.14705/rpnet.2019.36.957

Fondo, M., Jacobetty, P., \& Erdocia, I. (2018). Foreign language anxiety and self-disclosure analysis as personality traits for online synchronous intercultural exchange practice. In P. Taalas, J. Jalkanen, L. Bradley \& S. Thouësny (Eds), Future-proof CALL: language learning as exploration and encounters - short papers from EUROCALL 2018 (pp.59-63). Research-publishing.net. https://doi.org/10.14705/rpnet.2018.26.813

Fondo, M., \& Withanachchi, S. (2019). Crossing borders in business and economics classrooms: implementing telecollaboration to advance diversity and 21st century skills. Proceedings of the International Association for Business and Society (pp. 110-118).

Fondo, M., Lamolla, L., Withanachchi, S., \& Arnold, M. (in press). Intercultural exchanges for 21st-century skills development intercultural communicative competence. Intercultural Communicative Competence: A Competitive Advantage for Global Employability 2019: Conference Proceedings.

Friedman, H. P., \& Rubin, J. (1967). On some invariant criteria for grouping data. Journal of the American Statistical Association, 62(320), 1159-1178.

Gardner, R. C., \& MacIntyre, P. D. (1993). On the measurement of affective variables in second language learning. Language learning, 43(2), 157-194.

Gregersen, T. S., \& Horwitz, E. K. (2002). Language learning and perfectionism: anxious and non-anxious language learners' reactions to their own oral performance. The Modern Language Journal, 86(4), 562-570.

Hair, J. F., Black, W. C., Babin, B. J., \& Anderson, R. E. (2014). Multivariate data analysis. Pearson Education Limited Halkidi, M., Vazirgiannis, M., \& Batistakis, I. (2000). Quality scheme assessment in the clustering process. In European Conference on Principles of Data Mining and Knowledge Discovery (pp. 265-276). Springer.

Hartigan, J. A. (1975). Clustering algorithms. John Wiley \& Sons.

Helm, F. (2015). The practices and challenges of telecollaboration in higher education in Europe. Language Learning \& Technology, 19(2), 197-217.

Horwitz, E. K. (2017). On the misreading of Horwitz, Horwitz, and Cope (1986) and the need to balance anxiety research and the experiences of anxious language learners. In C. Gkonou, M. Daubney \& J.-M. Dewaele (Eds), New insights into language anxiety: theory, research and educational implications (pp. 31-50). Multilingual Matters.

Horwitz, E. K., Horwitz, M. B., \& Cope, J. (1986). Foreign language classroom anxiety. Modern Language Journal, 70(2), 2125-132. https://doi.org/10.1111/j.1540-4781.1986.tb05256.x

Horwitz, E. K., Horwitz, M. B., \& Cope, J. A. (1991). Foreign language classroom anxiety. In E. K. Horwitz \& D. J. Young (Eds), Language anxiety (pp. 27-39). Prentice Hall.

Horwitz, E. K., Tallon, M., \& Luo, H. (2010). Foreign language anxiety. In J. C. Cassady (Ed.), Anxiety in schools: the causes, consequences, and solutions for academic anxieties (pp. 95- 115). Peter Lang.

Hubert, L. J., \& Levin, J. R. (1976). A general statistical framework for assessing categorical clustering in free recall. Psychological Bulletin, 83(6), 1072-1080. 
Imai, Y. (2010). Emotions in SLA: new insights from collaborative learning for an EFL classroom. The Modern Language Journal, 94(2), 278-292

Jager, S., Kurek, M., \& O'Rourke, B. (2016). New directions in telecollaborative research and practice: introduction. In S. Jager, M. Kurek \& B. O'Rourke (Eds), New directions in telecollaborative research and practice: selected papers from the second conference on telecollaboration in higher education (pp. 1-15). Research-publishing.net. https://doi. org/10.14705/rpnet.2016.telecollab2016.486

Jauregi, K., \& Melchor-Couto, S. (2017). Motivational factors in telecollaborative exchanges among teenagers. In K. Borthwick, L. Bradley \& S. Thouësny (Eds), CALL in a climate of change: adapting to turbulent global conditions - short papers from EUROCALL 2017 (pp. 157-162). Research-publishing.net. https://doi.org/10.14705/rpnet.2017. eurocall2017.706

Kaiser, H. F. (1958). The varimax criterion for analytic rotation in factor analysis. Psychometrika, 23(3), 187-200.

Kim, S. Y. (2010). Is foreign language classroom anxiety context free or context dependent? Foreign Language Annals, 43(2), 187-189.

Kleinmann, H. H. (1977). Avoidance behaviour in adult second language acquisition. Language Learning, 27(1), 93107.

Kramsch, C. (2014). Teaching foreign languages in an era of globalization: introduction. The modern language journal, 98(1), 296-311.

Kunt, N. (1997). Anxiety and beliefs about language learning: a study of Turkish-speaking university students learning English in North Cyprus. Proquest Dissertations.

Lebart, L., Morineau, A., \& Piron, M. (2000). Statistique exploratoire multidimensionnelle. Dunod.

Lin, C. H., Warschauer, M., \& Blake, R. (2016). Language learning through social networks: perceptions and reality. Language Learning \& Technology, 20(1), 124-147.

Liu, M., \& Huang, W. (2011). An exploration of foreign language anxiety and English learning motivation. Education Research International, 1, 1-8.

Liu, M., \& Jackson, J. (2008). An exploration of Chinese EFL learners' unwillingness to communicate and foreign language anxiety. The Modern Language Journal, 92(1), 71-86.

Luo, H. (2014). Foreign language anxiety: past and future. Chinese Journal of Applied Linguistics, 36(4), 442-464.

MacIntyre, P. D., \& Gardner, R. C. (1991). Methods and results in the study of anxiety and language learning: a review of the literature. Language Learning, 41(1), 85-117.

Maloney, P., Grawitch, M. J., \& Barber, L. K. (2011). Strategic item selection to reduce survey length: reduction in validity? Consulting Psychology Journal: Practice and Research, 63(3), 162-175.

Matsuda, S., \& Gobel, P. (2004). Anxiety and predictors of performance in the foreign language classroom. System, 32(1), 21-36.

McNeil, L. (2014). Ecological affordance and anxiety in an oral asynchronous computer-mediated environment. Language Learning and Technology, 18(1), 142-159.

Milligan, G. W., \& Cooper, M. C. (1985). An examination of procedures for determining the number of clusters in a data set. Psychometrika, 50(2), 159-179. 
Moor, K. A. (2007). Intercultural communication and foreign language anxiety. Master dissertation. The Florida State University. http://diginole.lib.fsu.edu/etd

Müller-Hartmann, A. (2016). A task is a task is a task is a task... or is it? Researching telecollaborative teacher competence development - the need for more qualitative research. In S. Jager, M. Kurek \& B. O’Rourke (Eds), New directions in telecollaborative research and practice: selected papers from the second conference on telecollaboration in higher education (pp. 31-43). Research-publishing.net. https://doi.org/10.14705/rpnet.2016.telecollab2016.488

O'Dowd, R. (2016). Learning from the past and looking to the future of online intercultural exchange. In R. O'Dowd \& T. Lewis (Eds), Online intercultural exchange: policy, pedagogy, practice (pp. 273-298). Routledge.

O'Dowd, R. (2018). From telecollaboration to virtual exchange: state-of-the-art and the role of UNICollaboration in moving forward. Journal of virtual exchange, 1, 1-23. https://doi.org/10.14705/rpnet.2018.jve.1

Panayides, P., \& Walker, M. J. (2013). Evaluating the psychometric properties of the foreign language classroom anxiety scale for cypriot senior high school EFL students: the Rasch measurement approach. Europe's Journal of Psychology, 9(3), 493-516.

Pérez Paredes, P. F., \& Martínez Sánchez, F. (2001). A Spanish version of the FLCAS: revisiting Aida’s Factor analysis. RESLA, 14, 337-352.

Ratkowsky, D. A., \& Lance, G. N. (1978). A criterion for determining the number of groups in a classification. Australian Computer Journal, 10(3), 115-117.

Romesburg, H. C. (1984). Cluster analysis for researchers. Lifetime Learning Publications.

Satar, H. M. (2016). Meaning-making in online language learner interactions via desktop videoconferencing. ReCALL, 28(3), 305-325. https://doi.org/10.1017/S0958344016000100.

Scovel, T. (1978). The effect of affect on foreign language learning: a review of the anxiety research. Language Learning, 28(1), 129-142.

Tallon, M. (2006). Foreign language anxiety in heritage students of Spanish: to be (anxious) or not to be (anxious)? That is the question. Doctoral dissertation. University of Texas.

Tóth, Z. (2008). A foreign language anxiety scale for Hungarian learners of English. Working Papers in Language Pedagogy, 2, 55-77.

Van der Velden, B., Millner, S., \& Van der Heijden, C. (2016, April). Comparing the development of transversal skills between virtual and physical exchanges. In S. Jager, Sake, M. Kurek \& B. O'Rourke (Eds), New directions in telecollaborative research and practice: selected papers from the second conference on telecollaboration in higher education (pp. 217-224). Research-publishing. net. https://doi.org/10.14705/rpnet.2016.telecollab2016.510

Vinagre, M., \& Muñoz, B. (2011). Computer-mediated corrective feedback and language accuracy in telecollaborative exchanges. Language Learning \& Technology, 15(1), 72-103.

Ward, J. H., Jr. (1963). Hierarchical grouping to optimize an objective function. Journal of the American Statistical Association, 58, 236-244.

Yan, J., \& Horwitz, E. K. (2008). Learners' perceptions of how anxiety interacts with personal and instructional factors to influence their achievement in English: a qualitative analysis of EFL learners in China. Language Learning, 58, $151-183$ 


\section{Appendix 1}

\begin{tabular}{|c|c|}
\hline \multicolumn{2}{|c|}{ Items comparison between the FLCAS, AFLAQ, and T-FLAS } \\
\hline \multirow{12}{*}{ FLA } & $\begin{array}{l}\text { AFLAQ } 1 \text { - I feel nervous when I can’t write or express myself in the foreign language. } \\
\text { FLCAS } 1 \text { - I never feel quite sure of myself when I am speaking in my foreign language class. } \\
\text { T-FLAS } 8 \text { - During e-tandem language exchange I feel nervous when } \\
\text { I can’t express myself in the foreign language. }\end{array}$ \\
\hline & $\begin{array}{l}\text { FLCAS } 14 \text { - I would not be nervous speaking the foreign language with native speakers. } \\
\text { T-FLAS } 9 \text { - I am nervous speaking the foreign language in front of native speakers during e-tandem practice. }\end{array}$ \\
\hline & $\begin{array}{l}\text { FLCAS } 24 \text { - I feel very self-conscious about speaking the foreign language in front of other students. } \\
\text { AFLAQ } 8 \text { - I am not nervous speaking the foreign language in front of my classmates. } \\
\text { T-FLAS } 10 \text { - I feel uncomfortable in speaking a foreign language with my e-tandem partner. }\end{array}$ \\
\hline & $\begin{array}{l}\text { AFLAQ } 20 \text { - I feel nervous when talking in the foreign language. } \\
\text { T-FLAS } 11 \text { - I feel nervous when talking in the foreign language to someone I just met for e-tandem practice. }\end{array}$ \\
\hline & $\begin{array}{l}\text { FLCAS } 30 \text { - I feel overwhelmed by the number of rules you have to learn to speak a foreign language. } \\
\text { AFLAQ } 22 \text { - I feel overwhelmed by the number of grammatical rules I have to learn in the foreign language. } \\
\text { T-FLAS } 13 \text { - I feel overwhelmed by the number of grammatical rules I have to learn in the foreign language. }\end{array}$ \\
\hline & $\begin{array}{l}\text { AFLAQ } 23 \text { - I fear pronouncing words incorrectly in my foreign language class. } \\
\text { T-FLAS } 14 \text { - I fear pronouncing words incorrectly in my e-tandem speaking practice. }\end{array}$ \\
\hline & $\begin{array}{l}\text { AFLAQ } 25 \text { - I feel low self-confidence about speaking foreign language in front of the class. } \\
\text { T-FLAS } 15 \text { - I feel low self-confidence about speaking the foreign language during e-tandem sessions. }\end{array}$ \\
\hline & $\begin{array}{l}\text { AFLAQ } 27 \text { - I feel nervous when I am around more experienced foreign language users. } \\
\text { T-FLAS 17- I feel nervous when I am around more experienced foreign language users in e-tandem practices. }\end{array}$ \\
\hline & $\begin{array}{l}\text { AFLAQ } 28 \text { - I don’t feel anxious when learning a foreign language. } \\
\text { T-FLAS } 18 \text { - I feel anxious when learning a foreign language. }\end{array}$ \\
\hline & $\begin{array}{l}\text { FLCAS } 12 \text { - In language class, I can get so nervous I forget things I know. } \\
\text { AFLAQ } 29 \text { - In language class, I can get so nervous I forget things I know. } \\
\text { T-FLAS } 19 \text { - In e-tandem language practice I can get so nervous I forget things I know. }\end{array}$ \\
\hline & $\begin{array}{l}\text { FLCAS } 29 \text { - I get nervous when I don’t understand every word the language teacher says. } \\
\text { AFLAQ } 30 \text { - I feel anxious when I don’t understand what the teacher is saying in the foreign language. } \\
\text { T-FLAS } 20 \text { - I feel anxious when I don’t understand what my } \\
\text { e-tandem partner is saying in the foreign language. }\end{array}$ \\
\hline & $\begin{array}{l}\text { AFLAQ } 31 \text { - I feel anxious when I want to volunteer to say something but } \\
\text { can’t find the proper words to say it in my foreign language class. } \\
\text { T-FLAS } 21 \text { - I feel anxious when I want to say something but can’t find the proper } \\
\text { words to say it in the foreign language during the e-tandem speaking practice. }\end{array}$ \\
\hline \multicolumn{2}{|c|}{ T-FLAS original items } \\
\hline Technology & $\begin{array}{l}\text { T-FLAS } 1 \text { - I don’t like using technological devices. } \\
\text { T-FLAS } 2 \text { - I feel uncomfortable learning online. } \\
\text { T-FLAS } 4 \text { - I feel uncomfortable in video conferences. } \\
\text { T-FLAS } 5 \text { - I get very nervous when I have problems with technology during video conferences. }\end{array}$ \\
\hline $\begin{array}{l}\text { Social } \\
\text { interaction }\end{array}$ & $\begin{array}{l}\text { T-FLAS } 3 \text { - I don’t like to talk online to new people. } \\
\text { T-FLAS } 6 \text { - I feel uncomfortable interacting online. } \\
\text { T-FLAS 7 - I don’t enjoy talking about my private life online. }\end{array}$ \\
\hline
\end{tabular}




\begin{tabular}{|l|l|}
\hline $\begin{array}{l}\text { Original items } \\
\text { created for FLA }\end{array}$ & $\begin{array}{l}\text { T-FLAS 12 - I feel nervous talking to an e-tandem partner who has a } \\
\text { lower level of proficiency in the foreign language than me. } \\
\text { T-FLAS 16 - I feel nervous talking to an e-tandem partner who has a } \\
\text { higher level of proficiency in the foreign language than me. }\end{array}$ \\
\hline Discharged items \\
\hline FLCAS & $2-5,7-11,13,15-23,25-28,31-33$. \\
\hline AFLAQ & $2-7,9-19,21,24,26,32-33$. \\
\hline
\end{tabular}

\section{Appendix 2}

Sample of FLCAS dimensions in a collection of studies and versions compared to the T-FLAS.

\begin{tabular}{|c|c|c|c|c|c|}
\hline Author/Dimension & Dimension 1 & Dimension 2 & Dimension 3 & Dimension 4 & Dimension 5 \\
\hline Al-Saraj (2014) & $\begin{array}{l}\text { Communicative } \\
\text { apprehension }\end{array}$ & $\begin{array}{l}\text { Anxiety in the } \\
\text { learning processes } \\
\text { and situations }\end{array}$ & $\begin{array}{l}\text { Confidence in the } \\
\text { use of the FL }\end{array}$ & $\begin{array}{l}\text { Negative attitudes } \\
\text { towards language } \\
\text { learning }\end{array}$ & \\
\hline Aida (1994) & $\begin{array}{l}\text { Speech anxiety and } \\
\text { fear of negative } \\
\text { evaluation }\end{array}$ & $\begin{array}{l}\text { Fear of failing } \\
\text { the class }\end{array}$ & $\begin{array}{l}\text { Comfortableness } \\
\text { in speaking with } \\
\text { Japanese people }\end{array}$ & $\begin{array}{l}\text { Negative attitudes } \\
\text { towards the } \\
\text { Japanese class }\end{array}$ & \\
\hline $\begin{array}{l}\text { De la Morena } \\
\text { et al. (2011) }\end{array}$ & $\begin{array}{l}\text { Communicative } \\
\text { apprehension }\end{array}$ & $\begin{array}{l}\text { Anxiety in the } \\
\text { learning processes } \\
\text { and situation }\end{array}$ & $\begin{array}{l}\text { Confidence in the } \\
\text { use of the FL inside } \\
\text { the classroom }\end{array}$ & $\begin{array}{l}\text { Confidence in } \\
\text { the use of the } \\
\text { FL outside the } \\
\text { classroom }\end{array}$ & $\begin{array}{l}\text { Negative attitudes } \\
\text { towards language } \\
\text { learning }\end{array}$ \\
\hline Tóth (2008) & $\begin{array}{l}\text { Communicative } \\
\text { apprehension }\end{array}$ & $\begin{array}{l}\text { Fear of negative } \\
\text { social evaluation }\end{array}$ & $\begin{array}{l}\text { Attitude towards } \\
\text { the language } \\
\text { classroom }\end{array}$ & & \\
\hline $\begin{array}{l}\text { Liu and Huang } \\
\text { (2011) }\end{array}$ & $\begin{array}{l}\text { Fear negative } \\
\text { social evaluation }\end{array}$ & $\begin{array}{l}\text { Communicative } \\
\text { apprehension }\end{array}$ & Test anxiety & & \\
\hline $\begin{array}{l}\text { Cheng et al. (1999), } \\
\text { Matsuda and } \\
\text { Gobel (2004) }\end{array}$ & $\begin{array}{l}\text { General English } \\
\text { Performance }\end{array}$ & $\begin{array}{l}\text { Low self-confidence } \\
\text { in Speaking English }\end{array}$ & & & \\
\hline $\begin{array}{l}\text { Fondo, Jacobetty, } \\
\text { and Erdocia (2018) }\end{array}$ & $\begin{array}{l}\text { Classroom } \\
\text { participation }\end{array}$ & $\begin{array}{l}\text { Confidence in } \\
\text { using the FL }\end{array}$ & $\begin{array}{l}\text { Negative attitudes } \\
\text { towards language } \\
\text { learning }\end{array}$ & & \\
\hline T-FLAS & $\begin{array}{l}\text { Communicative } \\
\text { apprehension }\end{array}$ & $\begin{array}{l}\text { Anxiety in the } \\
\text { learning processes } \\
\text { and situations }\end{array}$ & $\begin{array}{l}\text { Online interaction } \\
\text { anxiety }\end{array}$ & Technophobia & \\
\hline
\end{tabular}




\section{Virtual Exchange?}

Published by University of Groningen Press | UGP, a not-for-profit press

Groningen, The Netherlands | UGP@rug.nl

(C) 2020 UNICollaboration (collective work)

(C) 2020 by Authors (individual work)

Journal of Virtual Exchange 2020

Edited by Carolin Fuchs, Cecilia Kennedy, and Müge Satar

Special issue edited by Marco Cappelini, Müge Satar, and Christelle Combe

Publication date: 2020/04/16

Journal of Virtual Exchange (JVE) is an online, open-access, peer-reviewed journal aimed at practitioners and researchers in the field known variously as virtual exchange, telecollaboration, or online intercultural exchange. It is the official journal of UNICollaboration (https://www.UNICollaboration.org/), the international academic organisation dedicated to supporting and promoting telecollaboration and virtual exchange in higher-level education.

Rights. The whole volume is published under the Attribution-NonCommercial-NoDerivatives 4.0 International licence (CC BY-NCND 4.0); individual articles may have a different licence. Under the CC BY-NC-ND licence, the volume is freely available online for anybody to read, download, copy, and redistribute provided that the author(s), editorial team, and publisher are properly cited. Commercial use and derivative works are, however, not permitted.

Disclaimer. University of Groningen Press does not take any responsibility for the content of the pages written by the authors of this article. The authors have recognised that the work described was not published before, or that it was not under consideration for publication elsewhere. While the information in this article is believed to be true and accurate on the date of its going to press, neither UniCollaboration nor University of Groningen Press can accept any legal responsibility for any errors or omissions. Additionally, the publisher makes no warranty, expressed or implied, with respect to the material contained herein. While University of Groningen Press is committed to publishing works of integrity, the words are the authors' alone.

Trademark notice. Product or corporate names may be trademarks or registered trademarks, and are used only for identification and explanation without intent to infringe.

Copyrighted material. Every effort has been made by the editorial team to trace copyright holders and to obtain their permission for the use of copyrighted material in this article. In the event of errors or omissions, please notify the publisher of any corrections that will need to by incorporated in future editions of this article.

Typeset by Research-publishing.net (https://research-publishing.net)

Noto fonts are open source. All Noto fonts are published under the SIL Open Font License, Version 1.1. Noto is a trademark of Google Inc. (https://www.google.com/get/noto/).

ISSN: 2647-4832 (online only)

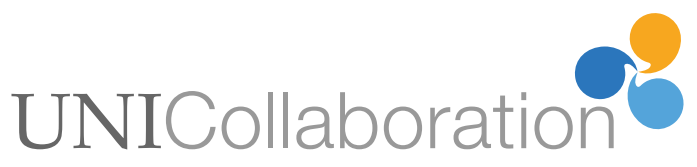

